\title{
The Students' Creative Thinking Process based on Wallas Theory in Solving Mathematical Problems viewed from Adversity Quotient /Type Climbers
}

\author{
Avissa Purnama Yanti ${ }^{1}$, Budi Koestoro ${ }^{2}$, Sugeng Sutiarso ${ }^{3}$ \\ 1,2,3 Universitas Lampung \\ ${ }^{1}$ Correspondence Address; avissa.purnama1011@students.unila.ac.id
}

\begin{abstract}
This research aims to describe the creative thinking process of students based on Wallas theory in solving mathematical problems. This type of research is qualitative research using qualitative descriptive methods. This research will begin by determining the type of Adversity Quotient using the Adversity Response Profile (ARP) test. The sampling technique is used positive sampling, selected 2 subjects to represent the climber type. The Data collection techniques are used written tests and interviews then analyzing the result based on indicators that fulfill Wallas creative thinking process and its level. The data analysis technique used is according to Milles and Huberman and the data validity technique uses technical triangulation Based on the results of data analysis, it was found that climber 1 is the climber with the creative thinking level that is very creative, Climber 1 is able to fulfill all stages of the creative thinking process by Wallas and its complete characteristics include fluency, flexibility, originality, elaboration. Whereas Climber 2 is a climber with creative thinking level that is creative, Climber 2 is able to fulfill all stages of the creative thinking process by Wallas but incomplete on its characteristics.
\end{abstract}

Kata Kunci: Adversity Quotient Climber types; Creative thinking process; the Solving Mathematical Problem; Wallas theory.

\section{INTRODUCTION}

The Science and the technology are developing rapidly in this era of globalization which has a positive and negative impact on human life. These changes and developments require that human resources have the capacity to think logically, critically, creatively, initiatively and adaptively to change and development (Prianggono, 2013). Based on the standard content of the basic and secondary education units of mathematics subjects that mathematics lessons are given to students have the ability to think logically, analytically, systematically, critically, and creatively, as well as the ability to cooperate (Febriani \& Ratu, 2018; Ngilawajan, 2013; Rahmatina, Sumarmo, \& Johar, 2014; Sasmita, Hudiono, \& Nurasangaji, 2015). In line with the curriculum development aims to improve the quality of the student in order to develop creative thinking skills so the student can follow the development of the era of globalization (Kurniawan, Kusmayadi, \& Sujadi, 2015). As in the 2013 Curriculum states that education aims to prepare Indonesian people to have the ability to live as productive, creative, innovative and effective (Sari, Ikhsan, \& Saminan, 2017). This shows the thinking ability becomes a demand in the era of technological development. One of the abilities to think is creative thinking (Andiyana, Maya, \& Hidayat, 2018; Bakır \& Öztekin, 2014; Niswah \& Siswono, 2017; Nurmasari, Kusmayadi, \& Riyadi, 2014).

The process of creative thinking is a process that combines logical thinking and divergent thinking. Divergent thinking is used to look for ideas to solve problems while logical thinking is used to verify the ideas into a creative solution, through a real picture can be obtained in explaining how creativity occurs (Machromah, Riyadi, \& Usodo, 2015). 
Creative thinking is a human mental activity in solving mathematical problems with the ability to find many possible answers or find the similiarity answer but in many different ways (Hendriyati, Trapsilasiwi, \& Susanto, 2017). The Creativity is one of the thinking skills that still lacks attention in mathematics learning. The teacher does not explore the students' creativity in solving problems because the problems given only have one correct answer. the The Teachers are not used teaching math problems that have more than one correct answer. The effect students being less interested in solving mathematical problems that demand creativity (Aziz, Kusmayadi, \& Sujadi, 2014; Sari et al., 2017).

The Characteristic of creative thinking include fluency (fluency that is able to generate many ideas and associations), flexibility (the flexibility of producing different ideas about the similiar stimulus and using different approaches to each other), originality (originality that produces new ideas, uncommon and rare) and elaboration (elaboration is applying a careful and detailed process to expand the simple stimulus available) (Andiyana et al., 2018; Bakır \& Öztekin, 2014; Rahmatina et al., 2014). The creative thinking theory is developed by Wallas (1926) is one of the most common categories are used to find out the creative thinking process which includes four stages, namely the preparation stage, incubation stage, illumination stage, and verification stage (Defitriani, 2014; Fauziyah, Usodo, \& Ch., 2013; Kurniawan et al., 2015; Rusdi, 2018; Sari et al., 2017). The Creative thinking become an important part of our daily lives. There is a need for the creative individuals who can handle the problems and help progress society with inovation and unique discoveries (Bakır \& Öztekin, 2014).

The problem solving in mathematics is an important thing that must be mastered for the student. The habit of students who are still using the usual ways to solve the problems one of the factors is the difficulty of finding other solutions and only fixated on the ways that have been obtained (Kurniawan et al., 2015). In line with this understanding means the ability to solve mathematical problems is one of the basic mathematical abilities that every student must claim (Syazali, 2015; Wijayanti \& Sungkono, 2017). The Problem solving in different ways that contributes to the development of students' creativity and critical thinking. This illustrates that creative thinking skills enable an individual to perceive a problem from various perspectives so the student enable to find creative solutions to the problems solving (Argarini, Budiyono, \& Sujadi, 2014). Learning to solve the problems is given many opportunities to connect mathematical ideas and to develop conceptual understanding. In fact, the ability to solve the problems in mathematics has not provided as good news, because the ability to solve the problems in mathematics is still the most fundamental problem. The ability of students to solve the mathematical problems is the basic for creating creative thinking students who automatically demand students to creativity.

Some research have been done about creative thinking that shows the students have a variety of levels of creative thinking and many students are still less creative in solving mathematical problems (Andiyana et al., 2018; Prianggono, 2013; Sasmita et al., 2015). The results of research conducted show that each student at each level of creativity has different characteristics in each stage of the thinking process (Aziz et al., 2014; Febriani \& Ratu, 2018). Many factors influence the level of students' creative thinking inproblems solving such as 
personality types (Aziz et al., 2014; Hasanah \& Putra, 2017), gender differences (Hendriyati et al., 2017; Sunarya, Kusmayadi, \& Iswahyudi, 2013), cognitive style (Argarini et al., 2014; Rahmatina et al., 2014; Susandi \& Widyawati, 2017), Adversity Quotient (Widyastuti, 2015) produces different creative thinking abilities.

Adversity Quotient (AQ) is an assessment that measures how a person's response to a problem can be empowered into an opportunity. Adversity Quotient can be an indicator to measure how strong a person can continue to survive in a difficulty, until finally the person can come out as a winner (climbers), retreat in the middle of the road (campers) or even do not want to accept the slightest challenge (quitters). Adversity Quotient (AQ) begins in cognitive development. Teenagers will learn how to respond or resolve some questions from the problems. The experience of children has begun to develop when they were born where they can improve or develop it. Referring to this, parents are required to pay good attention to their children so that the children can grow well (Hidayat \& Sariningsih, 2018; Rahmawati, Mardiyana, \& Usodo, 2015).

The Research by solving students' mathematical problems has been done previously. The Research uses learning models or methods in solving the mathematical problems (Putra, 2017; Wijayanti \& Sungkono, 2017; Wulandari, Mujib, \& Putra, 2016). The Research in solving mathematical problems using theory in solving mathematical problems to describe students' creativity has been done using the Schoenfield theory (Mujib, 2015). In addition the research uses Polya's theory in solving mathematical problems (Netriwati, 2016; Widyastuti, 2015). Then the research using Wallas's theory to think creatively in solving mathematical problems has also been carried out (Defitriani, 2014; Fauziyah et al., 2013; Kurniawan et al., 2015; Ratnasari, Hobri, \& Trapsilasiwi, 2015; Sari et al., 2017). The Research by solving mathematical problems using Wallas theory to see the students' creative thinking processes can be viewed from gender differences (Hendriyati et al., 2017), in terms of student intelligence (Hidaya \& Sutarni, 2017), in terms of cognitive style (Ngilawajan, 2013; Rahmatina et al., 2014; Susandi \& Widyawati, 2017) and viewed from mathematical anxiety (Machromah et al., 2015) and to see the creative thinking process of students in solving mathematical problems in terms of personality types (Aziz et al., 2014; Hasanah \& Putra, 2017) There has also been research on creative thinking using the theory of solving mathematical problems in terms of Adversity Quotient (AQ) (Widyastuti, 2015). This study conducted a renewal, the writer used Wallas theory to see the creative thinking process of students in terms of Adversity Quotient type of climbers. Based on the description that has been explained, the researcher is interested in knowing how the creative thinking process of students is based on Wallas theory in solving mathematical problems in terms of Adversity Quotient type of climbers.

\section{THE RESEARCH METHODS}

Based on the objectives of the reserch, the form of this research is qualitative research, while this research method is qualitative descriptive. Subject sampling in the research was using purposive sampling technique. Data collection techniques were used by researcher in 
this study was tests, interviews, and documentation. the interviews form were conducted by researcher was unstructured because more emphasizes on the specific interview. The instruments in this research were two types, namely the main instruments and supporting instruments. The main instrument is the researcher himself, while there are two kinds of assistive instruments, namely the determining instrument of the Adversity Quetient type, namely ARP (Adversity Respone Profile), and the mathematical problem solving instrument (description test) which is used to view the creative thinking process of students. Instrument in this research was conducted through expert judgment (assessment conducted by experts). Data analysis techniques were used in three stages, namely data reduction, data presentation and analysis conclusions (Sugiyono, 2016). Data validation and data validity in this research were done with technical triangles. The technique used in this study is by comparing the data collected using test and interview methods.

\section{THE RESULTS OF THE RESEARCH AND THE DISCUSSION}

The aim of the research is to describe the thinking process of students climbers in solving problems. The conclusion in qualitative research is a new finding that can be a description or description of an object (Sugiyono, 2016). The conclusions of the research based on the results of data analysis that has been collected through written test results and interview results by considering indicators of creative thinking according to Wallas theory and its level. moreover, the conclusions are about students' creative thinking processes and their level for each question based on climber type on Adversity Quetient (AQ) in solving mathematical problems.

The Process conclusions and the creative thinking levels are given using the following criteria (1) Students can have one of the stages / process of creative thinking in Wallas if students get at least 3 characteristics of the 4 stages of creative thinking. If only 2 of the stages that cannot be concluded. (2) Students can have the level of thinking process when the student is very creative to fulfill all stages of creative thinking wallas completely with the characteristics of the creative thinking process completely (not the conclusion (1)). (3) Students can have a level of thinking process that is creative if the students fulfill all stages of Wallas creative thinking completely but there is one characteristic of an incomplete creative thinking process (the conclusion (1)). (4) Students can have less creative the level of thinking process if students only get at least 2 stages of creative thinking of wallas but there are one or many characteristics of incomplete creative thinking processes (the results of the conclusion (1)). (5) Students can have not creative the level of thinking if students only fulfill at least 1 stage of Wallas creative thinking.

Based on the results of the description and data analysis, it can be seen that climber 1 tends to do the similiar creative thinking process on questions number 1 and number 2 . Climber 1 is able to answer questions correctly. Climber 1 is able to package prior knowledge into new ideas for solving mathematical problems in the material of equations and functions. The creative thinking process for Climber 1 is described in Table 1. 
Table 1. Creative Thinking Process Climber 1 in Solving Mathematical problem

\begin{tabular}{|c|c|c|c|c|c|c|}
\hline $\begin{array}{c}\text { Questi } \\
\text { ons } \\
\text { Numbe } \\
\text { r }\end{array}$ & $\begin{array}{c}\text { Wallas } \\
\text { Stages } \\
(x)\end{array}$ & $\begin{array}{l}\text { Characteri } \\
\text { stics of } \\
\text { thinking } \\
\text { creative }(y)\end{array}$ & $\begin{array}{c}\text { Achieveme } \\
\text { nt } y\end{array}$ & $\begin{array}{c}\text { Achieveme } \\
\text { nt of } \\
\text { conclusion } \\
x\end{array}$ & $\begin{array}{c}\text { The } \\
\text { creative } \\
\text { thinking } \\
\text { process } \\
\text { level }\end{array}$ & $\begin{array}{c}\text { The } \\
\text { Conclusion } \\
\text { Level of } \\
\text { Creative } \\
\text { Thinking } \\
\text { process }\end{array}$ \\
\hline \multirow[t]{16}{*}{1} & \multirow{4}{*}{$\begin{array}{l}\text { Prepara } \\
\text { tion }\end{array}$} & Fluency & $\sqrt{ }$ & \multirow[t]{4}{*}{ Preparation } & \multirow{16}{*}{$\begin{array}{l}\text { Very } \\
\text { Creative } \\
\text { (Adopting } \\
\text { the } \\
\text { conclusion } \\
\text { 2) }\end{array}$} & \multirow{32}{*}{$\begin{array}{l}\text { Very } \\
\text { Creative } \\
\text { (Adopting } \\
\text { the } \\
\text { conclusion } \\
\text { 2) }\end{array}$} \\
\hline & & Flexibility & $\sqrt{ }$ & & & \\
\hline & & Originality & $\sqrt{ }$ & & & \\
\hline & & Elaboration & $\sqrt{ }$ & & & \\
\hline & \multirow{4}{*}{$\begin{array}{l}\text { Incubat } \\
\text { ion }\end{array}$} & Fluency & $\sqrt{ }$ & \multirow[t]{4}{*}{ Incubation } & & \\
\hline & & Flexibility & $\sqrt{ }$ & & & \\
\hline & & Originality & $\sqrt{ }$ & & & \\
\hline & & Elaboration & $\sqrt{ }$ & & & \\
\hline & \multirow{4}{*}{$\begin{array}{l}\text { Illumin } \\
\text { ation }\end{array}$} & Fluency & $\sqrt{ }$ & \multirow[t]{4}{*}{ Illumination } & & \\
\hline & & Flexibility & $\sqrt{ }$ & & & \\
\hline & & Originality & $\sqrt{ }$ & & & \\
\hline & & Elaboration & $\sqrt{ }$ & & & \\
\hline & \multirow{4}{*}{$\begin{array}{l}\text { Verific } \\
\text { ation }\end{array}$} & Fluency & $\sqrt{ }$ & \multirow[t]{4}{*}{ Verification } & & \\
\hline & & Flexibility & $\sqrt{ }$ & & & \\
\hline & & Originality & $\sqrt{ }$ & & & \\
\hline & & Elaboration & $\sqrt{ }$ & & & \\
\hline \multirow[t]{16}{*}{2} & \multirow{4}{*}{$\begin{array}{l}\text { Prepara } \\
\text { tion }\end{array}$} & Fluency & $\sqrt{ }$ & \multirow[t]{4}{*}{ Preparation } & \multirow{16}{*}{$\begin{array}{c}\text { Very } \\
\text { Creative } \\
\text { (Adopting } \\
\text { the } \\
\text { conclusion } \\
\text { 2) }\end{array}$} & \\
\hline & & Flexibility & $\sqrt{ }$ & & & \\
\hline & & Originality & $\sqrt{ }$ & & & \\
\hline & & Elaboration & $\sqrt{ }$ & & & \\
\hline & \multirow{4}{*}{$\begin{array}{l}\text { Incubat } \\
\text { ion }\end{array}$} & Fluency & $\sqrt{ }$ & \multirow[t]{4}{*}{ Incubation } & & \\
\hline & & Flexibility & $\sqrt{ }$ & & & \\
\hline & & Originality & $\sqrt{ }$ & & & \\
\hline & & Elaboration & $\sqrt{ }$ & & & \\
\hline & \multirow{4}{*}{$\begin{array}{l}\text { Illumin } \\
\text { ation }\end{array}$} & Fluency & $\sqrt{ }$ & \multirow[t]{4}{*}{ Ilumination } & & \\
\hline & & Flexibility & $\sqrt{ }$ & & & \\
\hline & & Originality & $\sqrt{ }$ & & & \\
\hline & & Elaboration & $\sqrt{ }$ & & & \\
\hline & \multirow{4}{*}{$\begin{array}{l}\text { Verific } \\
\text { ation }\end{array}$} & Fluency & $\sqrt{ }$ & \multirow[t]{4}{*}{ Verification } & & \\
\hline & & Flexibility & $\sqrt{ }$ & & & \\
\hline & & Originality & $\sqrt{ }$ & & & \\
\hline & & Elaboration & $\sqrt{ }$ & & & \\
\hline
\end{tabular}

In table 1 , it can be seen that climber 1 at the preparation stage, on number 1 or 2 , climber 1 is able to fulfill all the characteristics of creative thinking namely fluency, flexibility, originality, elaboration. Climber 1 is able to explain in its own words what is known and what is asked in the question. Climber 1 is also able to describe what is known 
and what is asked directly by writing the modeling. At the incubation stage, Climber 1 is able to fulfill all the characteristics of creative thinking, namely fluency, flexibility, originality, elaboration. Climber 1 is able to explore possible strategies, climber 1 thinks of unique ideas / ways that are written in the form of paper scribbles using concepts that have been studied previously, namely the roots of quadratic equations for questions number 1 and for problem number 2 using the concept of area of rectangles and quadratic equations .Tahap iluminasi, climber 1 mampu memenuhi semua karakteriktik berpikir kreatif yaitu fluency, flexibility, originality, elaboration. Climber 1 is able to show the answer in a different way of solving using a unique concept that has been learned prevousiusly and completing it coherently. In the verification phase, Climber 1 is able to fulfill all the characteristics of creative thinking namely fluency, flexibility, originality, elaboration. Climber 1 is able to solve problems with various solutions and choose the right answer using unique methods, and is able to reassisment the truth of each step of the resolution that has been made on the results of its work.

Based on the description above, it can be concluded that Climber 1 in solving problems number 1 and 2 is able to fulfill all stages of the creative thinking process by Wallas and is able to fulfill all the characteristics of creative thinking in full including fluency, flexibility, originality, elaboration. The results are related with Fauziyah et al., (2013) that the Products of the problem submission must fulfill the importance of creativity in terms of overall (fluency), flexibility (flexibility) and originality, and the aspects of the process of creativy that emphasizes on the cognitive aspects of students when solving and proposing problems. Then the results of the research by Masfingatin \& Murtafi'ah (2016) show that students with climber type of adversity quotient can solve the problem properly. Then the results of the study Widyastuti (2015) that the students climber do the process of thinking assimilation at the stage of understanding the problem, developing a solution plan, solving problems according to the planning, and re-assessment of the results that have been obtained. Research by Kurniawan (2015) the students' creative thinking Climber in solving mathematical problems in the material Peluang (opportunities) get all stages of Wallas in the creative thinking. Based on the similar guidelines for drawing conclusions (2) with the results of previous research, Climber 1 is a climber with a level of very creative thinking.

Furthermore, based on the description and data analysis above, it can be seen that climber 2 views a different creative thinking process in number 1 and number 2 . There are several characteristics of creative thinking that are not achieved. Climber 2 answers the question by combining the knowledge previously with intuition. Nevertheless, Climber 2 is still able to answer the question with the correct ending. The creative thinking process for Climber 2 is described in Table 2. 
Table 2. The Creative Thinking Process Climber 2 in solving the mathematical Problem

\begin{tabular}{|c|c|c|c|c|c|c|}
\hline $\begin{array}{l}\text { The } \\
\text { questi } \\
\text { on } \\
\text { Num } \\
\text { ber }\end{array}$ & $\begin{array}{c}\text { Wallas } \\
\text { Stages } \\
(x)\end{array}$ & $\begin{array}{c}\text { Characteri } \\
\text { stic of The } \\
\text { Creative } \\
\text { Thinking } \\
(y)\end{array}$ & $\begin{array}{c}\text { Achieveme } \\
\text { nt } y\end{array}$ & $\begin{array}{c}\text { The } \\
\text { conclusion } \\
\text { of } \\
\text { Achieveme } \\
\text { nt } x\end{array}$ & $\begin{array}{c}\text { The Level } \\
\text { of Creative } \\
\text { Thinking } \\
\text { Process }\end{array}$ & $\begin{array}{c}\text { The } \\
\text { Conclusion } \\
\text { Level of } \\
\text { Creative } \\
\text { Thinking } \\
\text { Process }\end{array}$ \\
\hline \multirow[t]{16}{*}{1} & \multirow{4}{*}{$\begin{array}{l}\text { Preparati } \\
\text { on }\end{array}$} & Fluency & $x$ & \multirow{4}{*}{$\begin{array}{l}\text { Preparation } \\
\text { but not } \\
\text { fluency } \\
\text { (adopting } 1 \text { ) }\end{array}$} & \multirow{16}{*}{$\begin{array}{l}\text { Creative } \\
\text { (Adopting } \\
\text { conclusion } \\
\text { 1) }\end{array}$} & \multirow[t]{16}{*}{ Creative } \\
\hline & & Flexibility & $\sqrt{ }$ & & & \\
\hline & & Originality & $\sqrt{ }$ & & & \\
\hline & & Elaboration & $\sqrt{ }$ & & & \\
\hline & \multirow{4}{*}{$\begin{array}{l}\text { Incubatio } \\
\mathrm{n}\end{array}$} & Fluency & $\sqrt{ }$ & \multirow{4}{*}{$\begin{array}{l}\text { Incubation } \\
\text { but not } \\
\text { flexibilitty } \\
\text { (Adopting } \\
\text { 1) }\end{array}$} & & \\
\hline & & Flexibility & $x$ & & & \\
\hline & & Originality & $\sqrt{ }$ & & & \\
\hline & & Elaboration & $\sqrt{ }$ & & & \\
\hline & \multirow{4}{*}{$\begin{array}{l}\text { Illuminat } \\
\text { ion }\end{array}$} & Fluency & $\sqrt{ }$ & \multirow[t]{4}{*}{ Illumination } & & \\
\hline & & Flexibility & $\sqrt{ }$ & & & \\
\hline & & Originality & $\sqrt{ }$ & & & \\
\hline & & Elaboration & $\sqrt{ }$ & & & \\
\hline & \multirow{4}{*}{$\begin{array}{l}\text { Verificat } \\
\text { ion }\end{array}$} & Fluency & $\sqrt{ }$ & \multirow[t]{4}{*}{ Verification } & & \\
\hline & & Flexibility & $\sqrt{ }$ & & & \\
\hline & & Originality & $\sqrt{ }$ & & & \\
\hline & & Elaboration & $\sqrt{ }$ & & & \\
\hline \multirow[t]{16}{*}{2} & \multirow{4}{*}{$\begin{array}{l}\text { Preparati } \\
\text { on }\end{array}$} & Fluency & $x$ & \multirow{4}{*}{$\begin{array}{l}\text { Cannot be } \\
\text { concluded } \\
\text { (adopting 1) }\end{array}$} & \multirow{16}{*}{$\begin{array}{l}\text { Creative } \\
\text { (Adopting } \\
\text { conclusion } \\
\text { 3) }\end{array}$} & \\
\hline & & Flexibility & $\sqrt{ }$ & & & \\
\hline & & Originality & $\sqrt{ }$ & & & \\
\hline & & Elaboration & $x$ & & & \\
\hline & Incubatio & Fluency & $\sqrt{ }$ & \multirow[t]{4}{*}{ Incubation } & & \\
\hline & \multirow[t]{3}{*}{$\mathrm{n}$} & Flexibility & $\sqrt{ }$ & & & \\
\hline & & Originality & $\sqrt{ }$ & & & \\
\hline & & Elaboration & $\sqrt{ }$ & & & \\
\hline & \multirow{4}{*}{$\begin{array}{l}\text { Illuminat } \\
\text { ion }\end{array}$} & Fluency & $\sqrt{ }$ & \multirow[t]{4}{*}{ Illumination } & & \\
\hline & & Flexibility & $\sqrt{ }$ & & & \\
\hline & & Originality & $\sqrt{ }$ & & & \\
\hline & & Elaboration & $\sqrt{ }$ & & & \\
\hline & \multirow{4}{*}{$\begin{array}{l}\text { Verificat } \\
\text { ion }\end{array}$} & Fluency & $\sqrt{ }$ & \multirow[t]{4}{*}{ Verification } & & \\
\hline & & Flexibility & $\sqrt{ }$ & & & \\
\hline & & Originality & $\sqrt{ }$ & & & \\
\hline & & Elaboration & $\sqrt{ }$ & & & \\
\hline
\end{tabular}

On the table 2 it can be seen that climber 2 in the preparation stage is not able to fulfill the creative thinking characteristics, namely fluency in the question number 1 and for the question number 2 on fluency and elaboration. Climber 2 is less to explain what is known and what is asked in the question because Climber 2 thinks by using a mixture of intuition. 
The incubation Stage, Climber 2 is able to fulfill all the characteristics of creative thinking, namely fluency, flexibility, originality, elaboration on the question number 1 but does not fulfill flexibility in the question number 2. Climber 2 is able to explore possible strategies, thinking about unique ideas / ways that are expressed in scribbles paper uses intuition and a few concepts that have been learned previously. The Stage of illumination, Climber 2 is able to fulfill all the characteristics of creative thinking, namely fluency, flexibility, originality, elaboration. Climber 2 is able to show an answer with solving a different way by using a unique concept and solving it coherently. In the verification phase, Climber 2 is able to fulfill all the characteristics of creative thinking, namely fluency, flexibility, originality, elaboration. Climber 2 is able to solve problems with various solutions and choose the right answers using unique methods, and able to re-assesment the truth of each step that has been made on the results of their work.

Based on the description above, it can be concluded that Climber 2 is not able to fulfill the indicator of creative thinking process according to Wallas in full that the number 1 problem in the preparation phase on fluency and the incubation stage in flexibilty, while number 2 at the preparation stage is fluency and elaboration. But they still get the correct final result. Based on the guidelines for drawing conclusions (3) the climber 2 is a climber that have a level of creative thinking not very creative. The results of this study are the results of research by Fauziyah (2013) that mathematical problem solving ability in terms of adversity quetiont can improve the students' creativity. In line with research that is conducted by Aziz (2014) shows that in each stage of the creative thinking process there are different characteristics.

\section{CONCLUSION AND SUGGESTION}

Based on the description and data analysis above, it can be seen that the two climbers who were selected based on the ARP test were climber 1 and climber 2 . the research proved that climber students were the students' type who never gave up when facing a problem. Evidently, both climbers are able to answer questions with the correct ending. Climber 1 solves problems with the concepts of study experience while Climber 2 mixes them with intuition.

Both of these methods can make the two climber successfully solve the problem. Based on the description and data analysis above, even though both students are climber type, but they have different creative thinking processes and levels. Climber 1 is able to fulfill all indicators of the creative thinking process according to Wallas in complate. This shows that Climber 1 is a climber with a level of creative thinking that is very creative. It's different with Climber 2. Climber 2 is not able to fulfill the indicator of creative thinking processes according to Wallas completely, that the number 1 problem in the preparation phase on fluency and the incubation stage in flexibilty, while number 2 in the preparation stage is fluency and elaboration. Based on the guidelines conclusions, Climber 2 includes climber with a level of creative thinking that is creative only but not very creative.

The suggestion of the researcher after drawing conclusions from this research that is the teacher should pay attention to aspects of the type of Adversity Quotient (AQ) in learning. the Students with type climbers on AQ can help to maximize the learning process the example is 
being used as peer tutors or chairmen in study groups who can command their other friends. In addition, other researchers also need to develop the research so that they can reach all types of AQ.

\section{REFERENCES}

Andiyana, M. A., Maya, R., \& Hidayat, W. (2018). Analisis Kemampuan Berpikir Kreatif Matematis Siswa SMP pada Materi Bangun Ruang. JPMI: Jurnal Pembelajaran Matematika Inovatif, 1(3), 239-248.

Argarini, D. F. A., Budiyono, \& Sujadi, I. (2014). Karakteristik Berpikir Kreatif Kelas VII SMP N 1 Kragan dalam Memecahkan dan Mengajukan Masalah Matematika Materi Perbandingan Ditinjau dari Gaya Kognitif. JMEE, IV(2005), 1-12.

Aziz, A., Kusmayadi, T. A., \& Sujadi, I. (2014). Proses Berpikir Kreatif dalam Pemecahan Masalah Matematika Ditinjau dari Tipe Kepribadian Dimensi Myer-Briggs Siswa Kelas VIII MTs Nw Suralaga Lombok Timur Tahun Pelajaran 2013/2014. Jurnal Elektronik Pembelajaran Matematika ISSN: 2339-1685, 2(10), 1079-1093.

Bakır, S., \& Öztekin, E. (2014). Creative Thinking Levels Of Preservice Science Teachers In Terms Of Different Variables. Journal of Baltic Science Education ISSN 1648-3898, 13(2), 231-242.

Defitriani, E. (2014). Profil Berpikir Kreatif Siswa Kelas Akselerasi dalam Memecahkan Masalah Matematika Terbuka. JPM, 6(2), 65-76.

Fauziyah, I. N. L., Usodo, B., \& Ch., H. E. (2013). Proses Berpikir Kreatif Siswa Kelas X dalam Memecahkan Masalah Geometri Berdasarkan Tahapan Wallas Ditinjau dari Adversity Quotient (AQ) Siswa. Jurnal Pendidikan Matematika Solusi, 1(1), 75-90.

Febriani, S., \& Ratu, N. (2018). Profil Proses Berpikir Kreatif Matematis Siswa dalam Pemecahan Masalah Open-Ended Berdasarkan Teori Wallas. Mosharafa: Jurnal Pendidikan Matematika, 7(1), 39-50.

Hasanah, U., \& Putra, R. W. Y. (2017). Analisis Proses Berpikir Kreatif dalam Memecahkan Masalah Matematika Ditinjau dari Tipe Kepribadian Rational dan Artisan. Prosiding Seminar Nasional Pendidikan Matematika P-ISSN: 2579-941X E-ISSN : 2579-9444, 137-149.

Hendriyati, N. N., Trapsilasiwi, D., \& Susanto. (2017). Profil Berpikir Kreatif Siswa Kelas VII B SMP Negeri 6 Jember dalam Memecahkan Masalah Operasi Pecahan Berdasarkan Tahapan Wallas Ditinjau dari Perbedaan Gender. Kadikma, 8(2), 189-196.

Hidaya, A. R., \& Sutarni, S. (2017). Proses Berpikir Kreatif Siswa Kelas VIII SMP Negeri 2 Sawit dalam Memecahkan Masalah Pythagoras Berdasarkan Tahapan Wallas Ditinjau dari Tipe Intelegensi Siswa. Prosiding Seminar Nasional Pendidikan Matematika ISSN : 2528-4630, 1-8.

Hidayat, W., \& Sariningsih, R. (2018). Kemampuan Pemecahan Masalah Matematis dan Adversity Quotient Siswa SMP Melalui Pembelajaran Open Ended. JNPM (Jurnal Nasional Pendidikan Matematika), 2(1), 109-118.

Kurniawan, I., Kusmayadi, T. A., \& Sujadi, I. (2015). Proses Berpikir Kreatif Siswa Climber 
dalam Pemecahan Masalah Matematika pada Materi Peluang ( Penelitian pada Siswa Kelas XI IPA Semester II SMA Negeri I Polanharjo Tahun Ajaran 2014 / 2015 ). Jurnal Elektronik Pembelajaran Matematika, 3(6), 599-612.

Machromah, I. U., Riyadi, \& Usodo, B. (2015). Analisis Proses dan Tingkat Berpikir Kreatif Siswa SMP dalam Pemecahan Masalah Bentuk Soal Cerita Materi Lingkaran Ditinjau dari Kecemasan Matematika. Jurnal Elektronik Pembelajaran Matematika ISSN: 2339$1685,3(6), 613-624$.

Masfingatin, T., \& Murtafi'ah, W. (2016). Kemampuan Berpikir Logis Mahasiswa dengan Adverity Quotient Tipe Climber dalam Pemecahan Masalah. Jurnal Math Educator Nusantara, 2(1), 19-29.

Mujib, M. (2015). Membangun Kreativitas Siswa dengan Teori Schoenfeld pada Pembelajaran Matematika Melalui Lesson Study. Al-Jabar: Jurnal Pendidikan Matematika, 6(1), 53-62.

Netriwati, N. (2016). Analisis Kemampuan Mahasiswa dalam Pemecahkan Masalah Matematis menurut Teori Polya. Al-Jabar: Jurnal Pendidikan Matematika, 7(2), 181190. https://doi.org/10.24042/ajpm.v7i2.32

Ngilawajan, D. A. (2013). Proses Berpikir Siswa SMA dalam Memecahkan Masalah Matematika Materi Turunan Ditinjau dari Gaya Kognitif Field Independent dan Field Dependent. Pedagogia, 2(1), 71-83.

Niswah, N. T., \& Siswono, T. Y. E. (2017). Tahap Berpikir Kreatif Siswa dalam Mengajukan Masalah Matematika Berdasarkan Informasi Gambar dan Verbal. MATHEdunesa: Jurnal Ilmiah Pendidikan Matematika ISSN :2301-9085, 3(6).

Nurmasari, N., Kusmayadi, T. A., \& Riyadi. (2014). Analisis Berpikir Kreatif Siswa dalam Menyelesaikan Masalah Matematika pada Materi Peluang Ditinjau dari Gender Siswa Kelas XI IPA SMA Negeri 1 Kota Banjarbaru Kalimantan Selatan. Jurnal Elektronik Pembelajaran Matematika, 2(4), 351-358.

Prianggono, A. (2013). Analisis Proses Berpikir Kreatif Siswa Sekolah Menengah Kejujuruan (SMK) dalam Pemecahan dan Pengajuan Masalah Matematika pada Materi Persamaan Kuadrat. Pembelajaran Matematika, 1(2), 133-142.

Putra, F. G. (2017). Eksperimentasi Pendekatan Kontekstual Berbantuan Hands On Activity (HoA) Terhadap Kemampuan Pemecahan Masalah Matematik. Al-Jabar: Jurnal Pendidikan Matematika, 8(1), 73-80. https://doi.org/10.24042/ajpm.v8i1.1148

Rahmatina, S., Sumarmo, U., \& Johar, R. (2014). Tingkat Berpikir Kreatif Siswa dalam Menyelesaikan Masalah Matematika Berdasarkan Gaya Kognitif Reflektif dan Impulsif. Jurnal Didaktik Matematika ISSN: 2355-4185, 1(1), 62-70.

Rahmawati, N. D., Mardiyana, M., \& Usodo, B. (2015). Profil Siswa SMP dalam Pemecahan Masalah yang Berkaitan dengan Literasi Matematis Ditinjau dari Adversity Quotient (AQ). Jurnal Pembelajaran Matematika, 3(5).

Ratnasari, D., Hobri, \& Trapsilasiwi, D. (2015). Proses Berpikir Kreatif Siswa Berdasarkan Tingkat Berpikir Kreatif dalam Memecahkan Soal Cerita Sub Pokok Bahasan Keliling dan Luas Segi Empat Berbasis Tahapan Wallas ( The Creative Thinking Process Of Students Based On The Creative Thinking Level In Solv. Artikel Ilmiah Mahasiswa, 
$1(1), 1-5$.

Rusdi. (2018). Implementasi Teori Kreativitas Graham Wallas dalam Sekolah Kepenulisan di Pesantren Mahasiswa Hasyim Asy'ari Cabeyan Yogyakarta. Muslim Heritage, 2(2), 259-274.

S. Wijayanti, J. S. (2017). Pengembangan Perangkat Pembelajaran mengacu Model Creative Problem Solving berbasis Somatic, Auditory, Visualization, Intellectually. Al-Jabar: Jurnal Pendidikan Matematika, 8(2), 101-110.

Sari, A. P., Ikhsan, M., \& Saminan. (2017). Proses Berpikir Kreatif Siswa Dalam Memecahkan Masalah Matematika Berdasarkan Model Wallas. Beta: Jurnal Tadris Matematika, 10(1), 18-32.

Sasmita, Hudiono, B., \& Nurasangaji, A. (2015). Kemampuan Berpikir Kreatif Siswa dalam Pembelajaran Problem Posing pada Materi Bangun Datar. Jurnal Pendidikan Dan Pembelajaran, 4(1), 1-16.

Sugiyono. (2016). Metode Penelitian Pendidikan (Pendekatan Kuantitatif, Kualitatif, dan $R \& D)$. Bandung: Alfabeta.

Sunarya, L., Kusmayadi, T. A., \& Iswahyudi, G. (2013). Profil Tingkat Berpikir Kreatif Siswa Kelas VII SMP Negeri 16 Surakarta dalam Pemecahan Masalah Aritmatika Sosial Ditinjau dari Motivasi dan Gender. Jurnal Elektronik Pembelajaran Matematika ISSN: 2339-1685, 1(7), 712-720.

Susandi, A. D., \& Widyawati, S. (2017). Proses Berpikir dalam Memecahkan Masalah Logika Matematika Ditinjau dari Gaya Kognitif Field Independent dan Field Dependent. NUMERICAL: Jurnal Matematika Dan Pendidikan Matematika, 93-112. https://doi.org/10.25217/numerical.v1i1.122

Syazali, M. (2015). Pengaruh Model Pembelajaran Creative Problem Solving Berbantuan Maple II Terhadap Kemampuan Pemecahan Masalah. Al-Jabar: Jurnal Pendidikan Matematika, 6(1), 91-98.

Widyastuti, R. (2015). Proses Berpikir Siswa dalam Menyelesaikan Masalah Matematika berdasarkan Teori Polya ditinjau dari Adversity Quotient Tipe Climber. Al-Jabar: Jurnal Pendidikan Matematika, 6(2), 183-194.

Wulandari, P., Mujib, M., \& Putra, F. G. (2016). Pengaruh Model Pembelajaran Investigasi Kelompok berbantuan Perangkat Lunak Maple terhadap Kemampuan Pemecahan Masalah Matematis. Al-Jabar: Jurnal Pendidikan Matematika, 7(1), 101-106. 